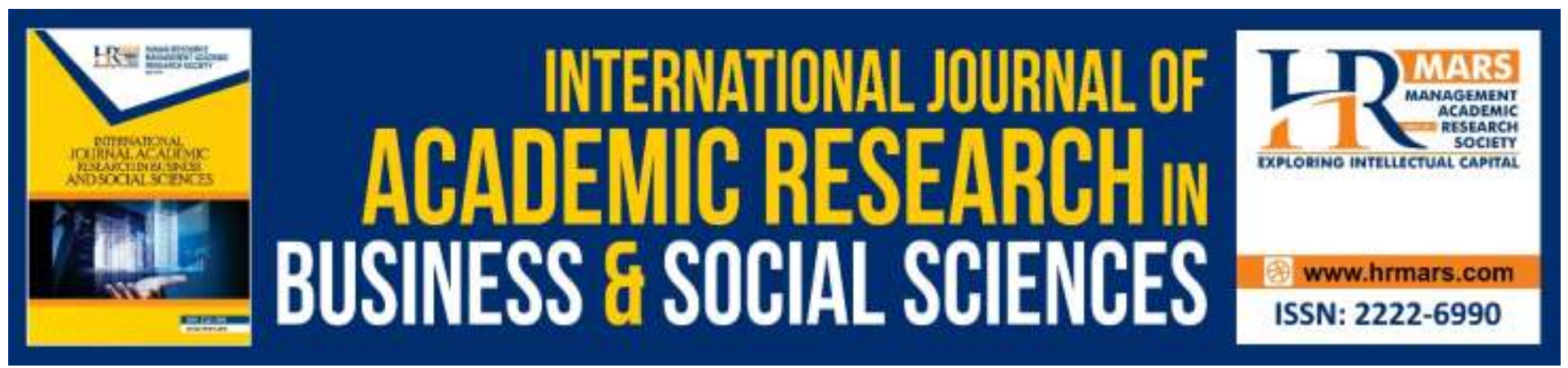

\title{
Fuzzy Tops is Ranking of Academic Programs' Competitiveness
}

Rosma Mohd Dom, Haliza Hasan, Ainon Mardhiyah Shahidin, and Nur Ainina Apandi

To Link this Article: http://dx.doi.org/10.6007/IJARBSS/v9-i13/6486

DOI: $10.6007 /$ IJARBSS/v9-i13/6486

Received: 22 August 2019, Revised: 17 September 2019, Accepted: 02 October 2019

Published Online: 23 October 2019

In-Text Citation: (Dom, Hasan, Shahidin, \& Apandi, 2019)

To Cite this Article: Dom, R. M., Hasan, H., Shahidin, A. M., \& Apandi, N. A. (2019). Fuzzy Tops is Ranking of Academic Programs' Competitiveness. International Journal of Academic Research in Business and Social Sciences, 9(13), 319-328.

Copyright: (c) 2019 The Author(s)

Published by Human Resource Management Academic Research Society (www.hrmars.com)

This article is published under the Creative Commons Attribution (CC BY 4.0) license. Anyone may reproduce, distribute, translate and create derivative works of this article (for both commercial and non-commercial purposes), subject to full attribution to the original publication and authors. The full terms of this license may be seen

at: http://creativecommons.org/licences/by/4.0/legalcode

Special Issue: Revolutionizing Education: Challenges, Innovation, Collaboration, 2019, Pg. 319 - 328 http://hrmars.com/index.php/pages/detail/IJARBSS

Full Terms \& Conditions of access and use can be found at http://hrmars.com/index.php/pages/detail/publication-ethics 


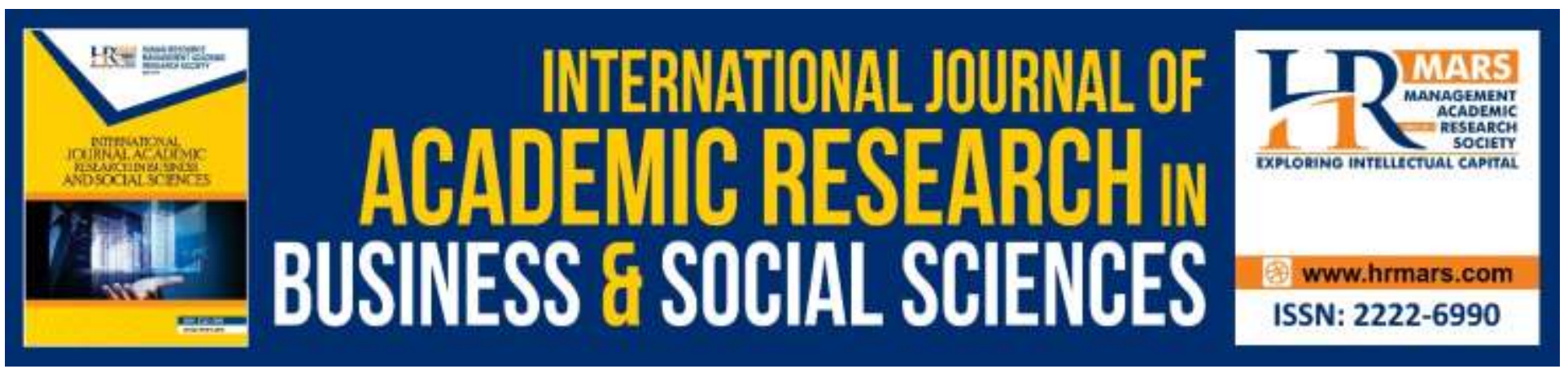

\title{
Fuzzy Tops is Ranking of Academic Programs' Competitiveness
}

\author{
Rosma Mohd Dom, Haliza Hasan, Ainon Mardhiyah \\ Shahidin, and Nur Ainina Apandi \\ Faculty of Computer and Mathematical Sciences, Universiti Teknologi MARA, \\ 40450 Shah Alam, Selangor Darul Ehsan, Malaysia
}

\begin{abstract}
Acknowledging the level of relevancy and competitiveness of academic programs is very important to education providers. This in return will benefit students enrolling in the programs. Measuring the level of relevancy and competitiveness of academic programs can be very subjective. In this paper, the application of a quantitative multi criteria decision making method known as Technique for Order of Preference by Similarity to Ideal Solution (TOPSIS) is presented. The relevancy and competitiveness of eleven academic programs offered at the Faculty of Computer and Mathematical Sciences, Universiti Teknologi MARA, Shah Alam are ranked based on seven criteria using modified Fuzzy TOPSIS. The criteria used in ranking of the academic programs were gathered from a group of twelve decision makers which comprises of top management of the faculty and university understudied. Quantitative ranking process was done based on data provided by the education provider itself. The seven criteria used include percentage of Dean's Award recipients, percentage of graduates with CGPA > 3.5, percentage of graduate employability, program popularity, percentage of students' entrance CGPA > 3.0, optimum enrollment based on allocation of places offered and future job demand. The weights of the criteria are determined using Fuzzy Analytical Hierarchy Process (AHP) technique. Modified Fuzzy TOPSIS are then used to rank the academic programs by incorporating the weights of criteria found. Future job demand and percentage of graduate employability are found to be the top two most important criteria used in the ranking process. Bachelor of Science (Hons) Statistics, Bachelor of Information Technology (Hons) Intelligent System Engineering and Bachelor of Science (Hons) Actuarial Science are found to be the top three most competitive programs offered by the institution. Consistency ratio test done indicated that the responses of decision makers are highly consistent thus reliable as reflected in the consistency ratio being < 0.1 .
\end{abstract}

Keywords: Academic Programs, Competitiveness, Ranking, TOPSIS 


\section{Introduction}

We are now in the era of Industry 4.0 where competitiveness amongst Higher Education Providers (HEP) is at its peak. Thus, universities need to have a mechanism in identifying the competitiveness of their academic programs that would enable them to plan and strategize on how to stay relevant in the education industries at the same time HEP could help the nation producing human resources apt for the current and future market demand. On the other hand, choosing the right academic program to embark on after completing secondary school education is an important step for school leavers since it is related to future employability and job prospect. Many factors have to be considered thus leading to a subjective decision making. In this paper, a multi criteria decision making method is proposed to rank eleven academic programs offered at the Faculty of Computer and Mathematical Sciences, UiTM Shah Alam based on seven criteria. Input from a group of twelve decision makers comprises of the top management of the faculty and university were gathered through questionnaires and historical data collected from four respective departments of the university while data on future job demand were collected from the Bureau of Labor Statistics. Weights of criteria were found using fuzzy AHP criteria weight determination method while the ranking was done using Fuzzy Modified TOPSIS method.

\section{Literature Review}

Multi Criteria Decision Making (MCDM) has been applied by many organizations in solving their daily decision-making problems as it is highly suitable for solving problems involving conflicting constraints and / or criteria. Furthermore, when carried out in fuzzy environment, Fuzzy Multi Criteria Decision Making (FMCDM), it is capable of solving more complicated problems which involved elements of subjectivity and vagueness (Harliza, Daud \& Hashimah, 2013). Performance evaluation involving human judgement is highly subjective since it commonly comprises of multicriteria, multi alternatives and several decision makers simultaneously, thus best done using multi criteria decision making method in fuzzy environment (Zadeh, 1965; Bellman \& Zadeh, 1970). Ranking of fuzzy numbers require similarity measure checked as to minimize the loss of information occurred in computational process. Similarity measurement in fuzzy environment is a very useful. Thus, new similarity measures have been introduced for fuzzy sets (Hashimah, Daud, Jamilah \& Aniza, 2018). For a more reliable result used in the study presented in this paper. The objective of this paper is to highlight the use of a fuzzy multi criteria decision making method for the ranking of competitiveness of academic programs offered at a higher-level education institution.

\section{Methods and Materials}

The methods undertaken for the ranking of academic programs competitiveness using Fuzzy modified TOPSIS is summarized in the research framework given in Fig.1. There are two major parts namely finding the weights for the seven criteria based on decision makers input using Fuzzy AHP criteria weight determination method followed by ranking of academic programs using Fuzzy Modified TOPSIS. Fuzzy AHP method is chosen due to its comprehensiveness in pairwise comparisons made on all criteria used (Prascevic \& Prascevic, 2016).

To cater for vagueness in multi criteria decision making process involving seven criteria and twelve decision makers, the ranking process was done in fuzzy environment as proposed by previous 
INTERNATIONAL JOURNAL OF ACADEMIC RESEARCH IN BUSINESS AND SOCIAL SCIENCES

Vol. 9, No. 13, Special Issue: Revolutionizing Education: Challenges, Innovation, Collaboration., 2019, E-ISSN: 2222-6990 ๑ 2019 HRMARS

researchers (Zadeh, 1965; Bellman \& Zadeh, 1970; Hashimah \& Mohamad, 2017; Hanif et al., 2013; Sulaiman \& Mohamad, 2013). Descriptions of data obtained from respective departments and questionnaires distributed to decision makers had used fuzzy linguistic terms. All triangular fuzzy scales and triangular fuzzy reciprocal scales used are as shown in Table 1 are following fuzzy notations introduced by Bozbura et al., 2007.

Table 1: Linguistic Scale of Importance

\begin{tabular}{lll}
\hline Linguistic Term of Importance & $\begin{array}{c}\text { Triangular } \\
\text { Scale }\end{array}$ & $\begin{array}{c}\text { Fuzzy } \\
\text { Fuzzy Reciprocal } \\
\text { Scale }\end{array}$ \\
\hline Just Equal (JE) & $(1,1,1)$ & $(1,1,1)$ \\
Equally More Important (EMI) & $(1 / 2,1,3 / 2)$ & $(2 / 3,1,2)$ \\
Weakly More Important (WMI) & $(1,3 / 2,2)$ & $(1 / 2,2 / 3,1)$ \\
Strongly More Important (SMI) & $(3 / 2,2,5 / 2)$ & $(2 / 5,1 / 2,2 / 3)$ \\
Very Strongly More Important (VSMI) & $(2,5 / 2,3)$ & $(1 / 3,2 / 5,1 / 2)$ \\
Absolutely More Important (AMI) & $(5 / 2,3,7 / 2)$ & $(2 / 7,1 / 3,2 / 5)$ \\
\hline
\end{tabular}




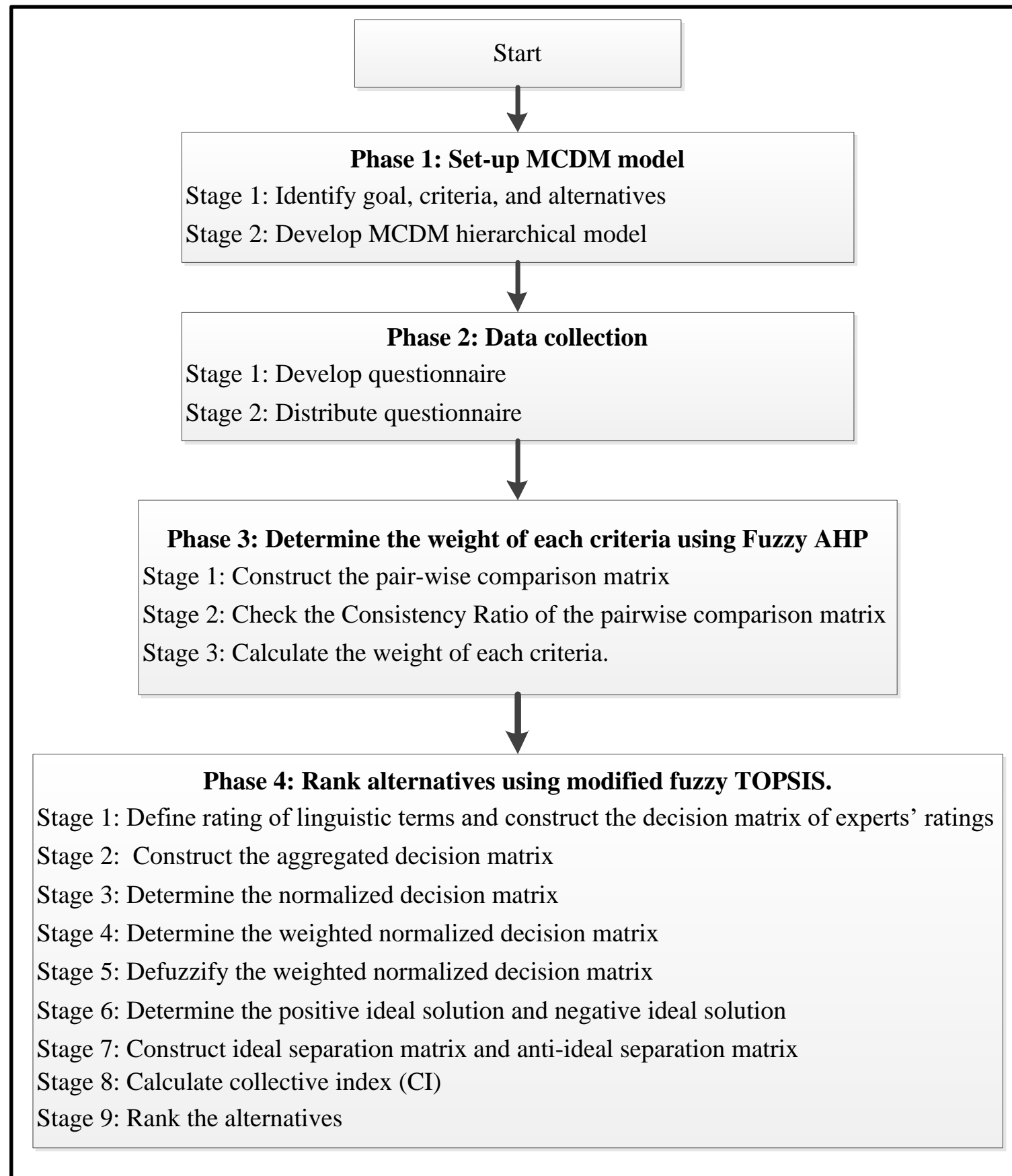

Fig. 1: Research Framework.

Fuzzy values were used to construct pairwise comparison matrices in which the pairwise comparison matrix given by $A_{k}$ is the $n \times n$ matrix where $n$ is the number of criteria for $k^{\text {th }}$ decision maker. The ratings of qualitative criteria are also described in linguistic terms expressed in triangular fuzzy numbers as shown in Table 2. 
INTERNATIONAL JOURNAL OF ACADEMIC RESEARCH IN BUSINESS AND SOCIAL SCIENCES

Vol. 9, No. 13, Special Issue: Revolutionizing Education: Challenges, Innovation, Collaboration., 2019, E-ISSN: 2222-6990 @ 2019 HRMARS

Table 2: Linguistic terms for the ratings

\begin{tabular}{ll}
\hline Linguistic terms & Triangular fuzzy number \\
\hline Very Good (VG) & $(9,10,10)$ \\
Good (G) & $(7,9,10)$ \\
Medium Good (MG) & $(5,7,9)$ \\
Fair (F) & $(3,5,7)$ \\
Medium Poor (MP) & $(1,3,5)$ \\
Poor (P) & $(0,1,3)$ \\
Very Poor (VP) & $(0,0,1)$ \\
\hline
\end{tabular}

Decision makers had used the linguistic terms to evaluate the ratings of alternatives (academic programs) with respect to each of the seven criteria. Experts' evaluations are then converted into decision matrix of academic program competitiveness rating. Algorithms for weight determination and ranking process are as described by Prascevic \& Prascevic (2016) and Vahdani, Mousavi, \& Tavakkoli-Moghaddam (2011). Findings on the criteria weights and ranking are discussed in the following section.

\section{Results and Discussion}

There are two major parts of the work done, thus the findings are divided into two parts accordingly. The first finding shown in Table 3 is on the criteria weight determination using fuzzy AHP.

Table 3: Weight of criteria found using fuzzy AHP

\begin{tabular}{ll}
\hline Criteria & Weights \\
\hline \% Dean's Awards & 0.1023 \\
\% Graduated CGPA > 3.5 & 0.1303 \\
\% Entrance CGPA > 3.0 & 0.1206 \\
\% Graduate Employability (GE) & 0.1836 \\
\% Program Popularity & 0.1455 \\
\% Optimum Enrolment Achieve & 0.1394 \\
\% Future Job Demand & 0.1782 \\
\hline
\end{tabular}

Inputs from twelve decision makers regarding the importance of criteria (reflected by its comparative weights) are found using fuzzy AHP. The pairwise comparisons were aggregated and final criteria weights are reported in Table 3. The three most important criteria found to be used for ranking of academic programs are Graduate Employability (GE), Future Job Demand and Program Popularity based on UPU application records. While the two least important criteria are obtaining Dean's Award and Entrance CGPA > 3.0. This finding indicates that decision makers involved had associated the competitiveness of an academic program with the good prospect of its graduates being employed upon completing the program. In addition to that, an academic program is regarded as competitive when it has very promising future job demand for the graduates. This is understandable due to high percentage of graduate unemployment currently reported in this country for certain job areas (Kalaimagal and Norizan, 2012). 
The criteria weights shown in Table 3 are based on responses from twelve decision makers. Consistency of all responses were checked using Consistency Ratio (CR) Index. The CR values are given in Table 4. The values of $C R$ are all less than 0.1 , thus the evaluations given by all decision makers are considered to be significantly consistent, hence acceptable to be used for the ranking of academic programs using Fuzzy Modified TOPSIS.

Table 4: Consistency Ratio for pairwise comparisons by twelve decision makers.

\begin{tabular}{ll}
\hline Decision maker & Consistency Ratio \\
\hline 1 & 0.0119 \\
2 & 0.0413 \\
3 & 0.0379 \\
4 & 0.0318 \\
5 & 0.0438 \\
6 & 0.0446 \\
7 & 0.0443 \\
8 & 0.0444 \\
9 & 0.0410 \\
10 & 0.0468 \\
11 & 0.0406 \\
\hline
\end{tabular}

Table 5 shows the findings on the ranking of eleven academic programs offered at the Faculty of Computer and Mathematical Sciences, UiTM Shah Alam found using Fuzzy Modified TOPSIS proposed by Vahdani, Mousavi, \& Tavakkoli-Moghaddam (2011) by incorporating the weights found at the earlier stage. 
INTERNATIONAL JOURNAL OF ACADEMIC RESEARCH IN BUSINESS AND SOCIAL SCIENCES

Vol. 9, No. 13, Special Issue: Revolutionizing Education: Challenges, Innovation, Collaboration., 2019, E-ISSN: 2222-6990 @ 2019 HRMARS

Table 5: Ranking of Academic Programs at the Faculty of Computer and Mathematical Sciences, UiTM using Fuzzy Modified TOPSIS.

\begin{tabular}{|c|c|c|c|}
\hline $\begin{array}{l}\text { Name of Academic } \\
\text { Program }\end{array}$ & Program Code & $\begin{array}{l}\text { Collective Index } \\
(\mathrm{Cl})\end{array}$ & Ranking \\
\hline CS240 & $\begin{array}{lll}\text { Bachelor of Information } \\
\text { Technology (Hons) }\end{array}$ & 39294007.9996 & 11 \\
\hline CS241 & $\begin{array}{l}\text { Bachelor of Science (Hons) } \\
\text { Statistics }\end{array}$ & 3.8640 & 8 \\
\hline CS242 & $\begin{array}{l}\text { Bachelor of Science (Hons) } \\
\text { Actuarial Science }\end{array}$ & 4.0948 & 2 \\
\hline CS243 & $\begin{array}{lll}\text { Bachelor of Information } \\
\text { Technology (Hons) Intelligent } \\
\text { System Engineering }\end{array}$ & 4.0257 & 1 \\
\hline CS244 & $\begin{array}{llr}\text { Bachelor of } & \text { Information } \\
\text { Technology } & \text { (Hons) Business } \\
\text { Computing } & & \\
\end{array}$ & 6.6695 & 10 \\
\hline CS245 & $\begin{array}{l}\text { Bachelor of Computer Science } \\
\text { (Hons) Data Communication and } \\
\text { Networking }\end{array}$ & 5.0966 & 5 \\
\hline CS246 & $\begin{array}{lll}\text { Bachelor of Information } \\
\text { Technology (Hons) } & \text { Information } \\
\text { System Engineering } & \\
\end{array}$ & 4.6514 & 4 \\
\hline CS249 & $\begin{array}{l}\text { Bachelor of Science (Hons) } \\
\text { Mathematics }\end{array}$ & 5.0664 & 6 \\
\hline CS230 & $\begin{array}{l}\text { Bachelor of Computer Science } \\
\text { (Hons) }\end{array}$ & 35481.6545 & 9 \\
\hline CS251 & $\begin{array}{l}\text { Bachelor of Computer Science } \\
\text { (Hons) Netcentric Computing }\end{array}$ & 4.4765 & 3 \\
\hline CS253 & $\begin{array}{l}\text { Bachelor of Computer Science } \\
\text { (Hons) Multimedia Computing }\end{array}$ & 49.6284 & 7 \\
\hline
\end{tabular}

The three most competitive academic programs identified are CS243 (Bachelor of Information Technology (Hons) Intelligent System Engineering), CS242 (Bachelor of Science (Hons) Actuarial Science) and CS 251 (Bachelor of Computer Science (Hons) Netcentric Computing). The three least competitive programs are CS244 (Bachelor of Information Technology (Hons) Business Computing), CS240 (Bachelor of Information Technology (Hons) and CS230 (Bachelor of Computer Science (Hons)). It is interesting to note that Actuarial Science program is equally competitive to the computing programs in particular the Intelligent System Engineering and Netcentric Computing programs. This could be due to the fact that graduates in Actuarial Science, Intelligent System Engineering and Netcentric Computing are highly sought after by the industries in the present era of data analytics, digital technology and gamification.

It is also very interesting to note that Bachelor of Information Technology (Hons), Bachelor of Information Technology (Hons) Business Computing and Bachelor of Computer Science (Hons) are 
placed at the bottom three of the ranking. The reason could be due to an excess number of graduates in IT leading to the future jobs availability for IT graduates in the future is shrinking rather steadily (Kalaimagal and Norizan, 2012).

As for the Bachelor of Computer Science, it could be due to the lack of interest among secondary school leavers to embark on a degree in computer science leading to a decrease in UPU applications among secondary school leavers to embark on at tertiary level (Suraya, Norsalawati \& Nasir (2017). This issues had been identified by the Ministry of Education of Malaysia in which efforts to inculcate interest on computer programming has been introduced at secondary school level (Syahanim et al., 2013).

UiTM and FSKM is currently doing a lot of intervention efforts as to enhance their graduates' employability by introducing many futuristic features required by employers such as reviews of curriculum to embed data analytics, entrepreneurship, gamification, $2 \mathrm{U} 2 \mathrm{I}$ and digital competencies to cater for IR 4.0 which is very much in line with the vision of the nation.

\section{Conclusion}

The findings of the study presented in this paper can help education providers and program owners to gauge their programs' relevancy and competitiveness. By knowing where, one stands, would enable education providers and program owners to plan and strategize on how to enhance the relevancy and competitiveness of their academic programs. This in return will benefit the students of respective programs now that their programs will be critically designed to suit current and future needs of the employers and to fulfil the demand of local and global human resource requirement.

\section{Acknowledgement}

The authors would like to thank Universiti Teknologi MARA for the financial assistance. This research is funded by the Academic and Research Assimilation (ARAS) Grants of UiTM.

(600-IRMI/DANA5/3/ARAS (0190/2016)).

\section{References}

Bellman, R. E. \& Zadeh, L. A. (1970). Decision Making in a Fuzzy Environment, 17(4), 141-164.

Bozbura, F. T., Beskese, A. \& Kahraman, C. (2007). Prioritization of human capital measurement indicators using fuzzy AHP. Expert Systems with Applications, 32(4), 1100-1112. https://doi.org/10.1016/j.eswa.2006.02.006

Chang, D. Y. (1996). Applications of the extent analysis method on fuzzy AHP. European Journal of Operational Research, 95(3), 649-655. https://doi.org/10.1016/0377-2217(95)00300-2.

Harliza, M. H., Daud, M. \& Hashimah, N. S. (2013). Solving decision making

Problems using fuzzy numbers with area dominance approach. AIP Conference proceedings of National Symposium on Mathematical Sciences, $18^{\text {th }}$ December 2012, Putrajaya, Wilayah Persekutuan.

Kalaimagal., R. and Norizan, M. Y. (2012). Employment issues among Malaysian information and communication technology (ICT) graduates: A case study. African Journal of Business Management. 6 (16), pp. 5615-5621. 
Hanif, M. H., Sulaiman, N. H. \& Mohamad, D. (2013). Solving Decision Making

Problems using Fuzzy Numbers with area dominance approach. AIP Conference Proceedings. 1522, p 237-244.

Hashimah, N. S. \& Daud, M. (2017). Extended FTOPSIS with Distance

and set Therotic -Based Similarity Measure. Indonesian Journal of Electrical Engineering and Computer Science. 9 (2), February 2018, pp. 387 394 ISSN: 2502-4752, DOI: 10.11591/ijeecs.v9.i2.pp387-394.

Hashimah, N. S., Daud, M., Jamilah, M. S. \& Aniza, S. A. (2018). Extended

FTOPSIS with distance and set theoretic-based similarity measure. Indonesian Journal of Electrical Engineering and Computer Science, 9(2), 387-394.

Sulaiman, N.H. \& Mohamad, D. (2013). A set theoretic similarity measure for fuzzy soft sets and its applications in group decision making. AIP Conference Proceedings. 1522, $\mathrm{p}$ 229-236.

Prascevic, N., \& Prascevic, Ž. (2016). Application of fuzzy AHP method based on

eigenvalues for decision making in construction industry. 1. https://doi.org/10.17559/TV20140212113942.

Suraya, B, Norsalawati, W. N. I. (2017). Integration of STEM

Education in Malaysia and Why to STEAM. International Journal of Academic Research in Business and Social Sciences. 7(6).

Syahanim, M. S., Zarina, S., Hairulliza, M. J. (2013). Analysis of Research in Programming Teaching Tools: An Initial Review. Procedia - Social and Behavioral Sciences. 103. pp 127 - 135. 13th International Educational Technology Conference.

Vahdani, B., Mousavi, S. M., \& Tavakkoli-Moghaddam, R. (2011). Group decision making based on novel fuzzy modified TOPSIS method. Applied Mathematical Modelling, 35(9), 4257-4269. https://doi.org/10.1016/j.apm.2011.02.040

Zadeh, L. A. (1965). Fuzzy sets *. University of California, Berkeley, California. 